JURNAL CONCIENCIA

Vol. XX No. 1, Juni 2020, 28-39

p-ISSN: 1412-2545 e-ISSN: 2622-7304 http://jurnal.radenfatah.ac.id/index.php/conciencia

\title{
STRENGTHENING RELIGIOUS EDUCATION FOR FAMILY RESILIENCE IN YOGYAKARTA MUSLIM MINORITIES
}

\author{
Yusron Masduki ${ }^{1}$, Hanif Cahyo Adi Kistoro ${ }^{2}$, Sutipyo Ru'iya ${ }^{2}, \operatorname{Sutarman}^{4}$, Sukirman $^{5}$ \\ 1,2,3,4,5 Universitas Ahmad Dahlan, Yogyakarta, Indonesia \\ Email:yusron.masduki@pai.uad.ac.id
}

\begin{abstract}
The family resilience is very important of minority Muslim societies. Family and environmental factors become the main thing. The role of parent and community leaders is one of the keys to the success of strengthening religious aspects for minority Muslims. This research will seek to answer the questions about how to strengthen religious education for family security among minority Muslims. This research approach used a descriptive narrative. It related the life experience of a person or group which was important data of explaining the meaning of the phenomenon to be studied. The participants of this research were the parents and community leaders of Banjarasri Kulon Progo village of Yogyakarta which total were 12 persons. The data collection techniques used: (1) observation; (2) in-depth interviews. Data analysis used analytical coding, where this analysis described the story, chronologically the events that become a turning point with the stages of data organization, reading, describing data in codes and themes, classification of data, interpreting data, and presenting data. The research findings related to strengthening the values of religious education in Muslim minority families carried out in three ways, namely: (1) strengthening in the field of creed and morals; (2) strengthening in education, and (3) strengthening in economics.
\end{abstract}

Keywords: $\quad$ Education; Family; Minorities; Muslim.
Abstrak: Ketahanan keluarga sangat penting bagi masyarakat Muslim minoritas. Faktor keluarga dan lingkungan menjadi hal utama. Peran orang tua dan tokoh masyarakat adalah salah satu kunci keberhasilan penguatan aspek agama bagi Muslim minoritas. Penelitian ini akan berusaha menjawab pertanyaan tentang bagaimana memperkuat pendidikan agama untuk keamanan keluarga di kalangan Muslim minoritas. Pendekatan penelitian ini menggunakan naratif deskriptif. Ini terkait dengan pengalaman hidup seseorang atau kelompok yang merupakan data penting untuk menjelaskan makna fenomena yang akan dipelajari. Partisipan dalam penelitian ini adalah orang tua dan tokoh masyarakat Desa Banjarasri Kulon Progo Yogyakarta yang berjumlah 12 orang. Teknik pengumpulan data yang digunakan: (1) observasi; (2) wawancara mendalam. Analisis data menggunakan pengkodean analitik, di mana analisis ini menggambarkan cerita, secara kronologis peristiwa yang menjadi titik balik dengan tahapan pengorganisasian data, membaca, mendeskripsikan data dalam kode dan tema, klasifikasi data, menafsirkan data, dan menyajikan data. Temuan penelitian terkait penguatan nilai-nilai pendidikan agama pada keluarga minoritas Muslim dilakukan dengan tiga cara, yaitu: (1) penguatan di bidang akidah dan akhlak; (2) penguatan di bidang pendidikan, dan (3) penguatan di bidang ekonomi.

Kata kunci: pendidikan; keluarga; minoritas; Muslim. 
INTRODUCTION

Education in the era of globalization has an important role in forming a family resilience. Not just as a form of transformation of science, education becomes a provision and the ability of an individual to deal with global conditions. The group of individuals who are already strong will become a small group called the family. It is certainly that the education provided is not only technical education but also education that directs to abilities and strength of mental, psychological and spiritual.

Religious education plays an important role in realizing religious values in the form of religious subjects in each education unit (Prasetiya, 2019). Education related to religious knowledge remains an education that must be given and strengthened in forming the character of children to date.

According to An-Nahlawi (2001), education comes from the word at tarbiyyah which has a basic understanding of increasing, growing, improving, guiding, keeping and maintaining. In Indonesian, education comes from word didik who were given the prefix - pe- and suffix -an- which has the meaning of changing the attitudes and behavior of a person or group in an effort to mature humans (Aziz, 2003). It is supported by Donald (1995) who states that education is a process or an activity which is directed at producing desirable changes in the behaviour of human beings. Education in terms of meaning as a process that aims to change human behavior in accordance with what is desired. While according to Achmadi (1992), education is actions taken consciously with the aim of maintaining and developing the nature and potential (resources) of human beings towards the formation of whole human beings (insan kamil). Thus, education is an effort or action given by someone consciously towards the development of others towards a better direction towards the formation of behavior, ways of thinking and behaving so that potential is maintained towards the whole human being. Whereas according to Achmadi (1992), "Islamic education is more specifically emphasized efforts to develop the religious nature of the subject of students to better understand, live and practice the teachings of Islam" (p. 35).

Based on the definitions above, it clearly shows that education is a process to form and develop human potential to produce behaviors that are in accordance with the objectives of education which in Islam specifically is to form moral behavior.

The family is one of the basis of the education process. The family has a strong influence in the process of forming a child's behavior or morals. According to the Oxford Encyclopedia Dictionary of the Modern Islamic World, the family is the smallest unit in the most basic social sphere (as cited in Achmadi, 1992). Family will differ in understanding according to the context and culture of the community. In the Western world, family is defined as a "nuclear family", consisting of one or two parents and their children. While in eastern cultures, according to Arabic the family is ahl or ahila, including grandparents, uncles, aunts, and cousins of the two marriage ties. In a broadest sense, the family can be seen as an even larger unit, which is the same as the people, or groups of believers, Muslims, or the family itself (Elposito, 2002).

The earliest educational process is formed in the family environment. The process of socialization and individual development begin to form. Child's personality begins to be formed and parents begin to teach about the inculcation of moral values, especially religious values (Khatib, 2008). Islam places a very important position for parents as the first educators and foremost for the introduction, education and practice of religious values to children in their families (Rianawati, 2019). 
Families can be divided into 2 namely small families (nuclear family) consisting of husband, wife and children and extended family consisting of people who have blood ties from a group. Extended family usually consist of parents, grandparents, uncles, aunts, nieces and so on. (Mufidah, 2008, p. 64).

The Islamic concept of family understanding is a unity of relationship between man and woman through a marriage contract according to Islamic teachings. Marriage contract will become legality legally religious existence of children and offspring produced (Faqih, 2001).

The family has several functions in the context of social life, including: first, a biological function, where human biological desires are accommodated in the bond of a legal marriage according to legal and religious norms. Second, educational function, where family is required to provide education for family members, especially children for the provision of the next life. Children's first experience and knowledge are obtained from the family. Parents have an important enough role to guide and develop the moral, spiritual, intellectual and professional aspects of children. Third, religious function, the family is required to provide religious education to the whole family. The family as a place to inculcation religious values and practices of worship in daily life. Fourth, protective function, where the family is a safe place from the threat of any party.

Based on the definitions above, it is clear that family is obliged to care for and educate their children. Parents are responsible for the needs of all family members both from moral, spiritual and professional education in Islamic teachings as part of worship to Allah SWT and to get happiness in the world and hereafter. As mentioned in Syamil al-Qur'an (2010) Surah At-Tahrim (66) verse 6:

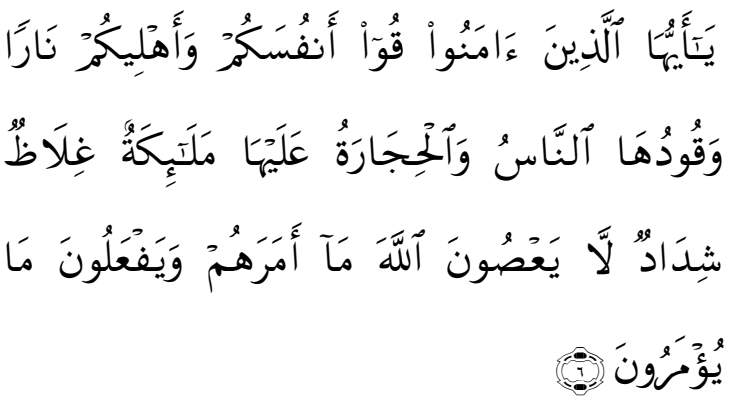

Meaning: "you who have believed, protect yourselves and your families from a Fire whose fuel is people and stones, over which are (appointed) angels, harsh and severe; they do not disobey Allah in what He commands them but do what they are commanded".

The meaning of the verse above clearly instructs parents to always provide education and care for families from any condition and anywhere. The creation of ideal conditions can be done in the Islamic community which is the majority community. These ideal conditions may differ slightly in the Muslim minority community. The minority muslims living in certain groups of society generally experience various problems ranging from religious animosity, lack of growth in the drive to preserve Islamic values, limited access to outside and others. They will be faced with the conditions of the surrounding community who make efforts to hamper the application of Islamic values.

The challenge of minority Muslims is not only as immigrants (muhajir) but also becoming mujahid, because they must maintain the creed in a different social environment. The minority Muslims are demanded more to be able to organize in maintaining and strengthening identity with fellow Muslims. Another demand faced by minority Muslims is also the ability to dialogue with non-Muslims for the common goal of living in harmony and peace.

Linking these issues is clearly needed reinforcement in the form of 
directed and structured education in dealing with obstacles in the community. Family education is an effective media for enhancing and building resilience of Muslim households. The existence of minority Muslim family education needs to be emphasized as a basis for continuing Islamic culture in the Muslim family environment itself. The education function seeks to adjust by harmonizing the old culture with the new culture proportionally and dynamically (Nizar, 2013).

Strengthening minority Muslim families are intended to anticipate the phenomenon of ethnic, socio-cultural conflict that often arises in the midst of society. Along with the resistance groups and groups that occur potential conflicts can arise at any time. The most common factors that arises in conflicts are caused by differences in ethnicity, religion, race, ethnicity and culture (Ahmad, 2013).

The theme of minority Muslims has been done by several studies and research that have been published in the form of journals. In research written by Arifin et al. (2019) illustrate the religious freedom of minority Muslims living in secular countries. Australia as one of the countries considered secular has consistently protected the religious freedom of its citizens and the Australian government, in dealing with social and religious issues, and law enforcement, has worked professionally. Although Muslims as a minority also face the reality of discrimination cases that come from fundamentalist Christians, but through dialogue and interfaith cooperation can be resolved well. This article stated that, Muslim minorities in Australia's multicultural society could enjoy their religious freedom. The practiced of tolerance between religions were stronger than the tensions and conflicts that occur.

Adawiyah and Jamaludin (2016) emphasize that local scale Islamic education in Muslim minority areas needs to be strengthened. Islamic boarding schools as one of the institutions that can strengthen Islamic education among Muslim minorities with the concept of local education.

Al Arifin (2012) explained the Implementation of Multicultural Education in the Praxis of Education in Indonesia. The main study in this research is about multicultural education as a progressive approach to transforming holistic education. This study provides a critique of weaknesses, failures and discrimination in the world of education. The implementation of multicultural education is based on five dimensions: (1) content integration, (2) the process of compiling knowledge, (3) reducing prejudice, (4) equal pedagogy, and (5) school culture and empowering school structures.

In line, Wahib (2012) also explained about the struggle for Islamic education in Muslim minority areas in Bali. In this research it was concluded that, First, it related to the lives of Muslim minorities at school before and after the bombing: relationships that were initially good then became damaged; Second, internal problems of Islamic Education $(P A I)$ teachers: Islamic education (PAI) teachers in Bali face problems of a very wide range in terms of areas of life: schools, classrooms, and social life; Third, material in the local curriculum: the need to include material about respect for adherents of different beliefs.

Answering this issue it is clear that education especially in strengthening families needs to find an appropriate model for minority Muslims that coexist in a non-Muslim majority environment. In Indonesia, some areas of Muslim society are a minority. This has been one side for a long time. Muslim minorities coexist with majority groups whether Christian or Hindu.

Conditions above are also experienced by minority Muslim groups in the Banjarasri area of Progo Yogyakarta. Banjarasri is a village on the edge of the Progo river with a population of around 4.642 people, who mostly adhere to 
religions outside of Islam. The details of the population who adhere to Islam are 1.957 people, while those of other religions are 2.860 people (Monografi, 2015).

The difference in the number of inhabitants affects the lives of minority Muslims who are there. In the governance structure, almost all village officials, starting from the neighbourhood head, the head of hamlets, village head to subdistrict head are occupied by non-Muslims. In addition, social interaction is also more dominant in non-Muslim groups. The real effect of this problem is that many Muslim interests have not been accommodated. In terms of worship, minority Muslims cannot do freely because they have to consider the interests of the majority. Islamic education institutions do not stand much, on the contrary non-Muslim schools are more numerous.

The advantage of minority Muslims in the village of Banjarasri is the high enthusiasm of minority Muslim families to educate their children in terms of religion. Although they have to go to a place that is quite far because of the limitations of the mosque and prayer rooms. At this time, the lives of minority Muslims can still run, but in the future this problem can be increasingly developed when the generation of parents is getting smaller and young people are also getting less good in terms of numbers or the desire to care for mosques and prayer rooms in maintaining religious endurance. Plus the tendency of young people who will wander in search of a better livelihood.

Based on the phenomena that occur, this research aims to dig deeper into the experience of the Muslim minority family in the Banjarasri Kulonprogo area of Yogyakarta in conducting religious strengthening as a form of strengthening family resilience from the aspects of aqidah and morals, education and economics.

\section{RESEARCH METHOD}

The research focused on strategies to strengthen religious education for minority families in the Yogyakarta area. Based on this focus, researchers used a narrative approach, where this approach would describe a story about the experience of individuals (someone) or some people about their life experiences related to concepts or phenomena that occur (Creswell, 2015, p. 349). The narrative approach was used in this study to translate narratives that are understood as text and written by telling events as a chronology (Czarniawska, 2004, p. 235).

The location of this research was carried out in the Yogyakarta area, precisely in the area of Kulon Progo Regency. Consideration in choosing this location, because geographically, the Banjarasri region was a border area that was in good access in the economic, social and information sectors was still limited. In accordance with historical factors, this area was one of the areas where Christianity spreads in the Yogyakarta region. Thus, it made one of the centers of the majority of non-Muslim regions.

The subjects in this research was taken by purposive sampling technique where the criteria for selecting subjects were designated for minority Muslim parents who were selected as participants in this research. The selection of participants is done to parents who are categorized in several educational and social statuses, namely those who have elementary school, junior high school, high school and university. Whereas, the category for social status was people who work as teachers or educators and farmers or laborers. This is done with the aim of seeing how experiences and strategies were carried out by families with high and low education.

The data were collected by observation and interview techniques. Observation was the activity of observing and recording a phenomenon with the help of an instrument and recording it for 
scientific purposes (Morries, 1973). Observation activities aimed at observing activities related to strengthening religious education for children, namely prayer and recitation Qur'an. Observation activities are carried out to families who were the subject of research by observing what is done at prayer and recitation Qur'an by using the rubric instrument assessment of the intensity of the prayer and studying and other interactions conducted between family members.

Besides, the researchers conducted field observations in order to obtain stronger data, researchers conducted indepth interviews with 12 participants consisting of 2 religious leaders and 10 parents in accordance with predetermined categories. The selection of 10 participants is based on a research design according to Creswell (2007, p. 54) that exploratory phenomena can be carried out on heterogeneous participants between 3-15 people. Two categories determined for participants are Muslim parents who have teenagers (junior high school, high school and university) and have education levels from elementary to university level. Interviews were conducted using interview protocol instruments that contained questions about the activities carried out by parents in their daily lives in educating about religious matters. Content analysis is performed after the interview data is collected which is made in the form of verbatim and coding. The final results obtained after carrying out the steps of analysis from the start of data organization, reading, memoing, describing data in coding and themes, classifying data, interpreting data and presenting data based on the results of observation and field interviews.

\section{RESEARCH FINDINGS}

Strengthening in The Field of Creed and Morals

Strengthening religious education in the Banjarasri village cannot be separated of factors or influences of religious figures. Although in the family environment parents (mother and father) have an important role, but the existing religious leaders also had a role that was no less important. One of the findings were the motivation and encouragement of the cleric or elder who was always provided understanding to parents. The existence of this motivation or encouragement strengthens of parents to provide an understanding of religion even though it was limited. One example was when entering the fasting month, many people around the village did not fast because they have other religions, but parents still gave an understanding to children to keep fasting. This is reinforced from the results of an interview with one of the Islamic religious leaders (ES) who stated "here to provide religious strengthening given to his parents first, for instance, we often say to exemplify in carrying out compulsory worship, especially prayer and fasting. Our Muslim environment is minority, so the temptations are many and various. With encouragement given to parents, then parents who meet their children every day will tell and give an example ".

Not only in terms of creed, in terms of morals also must be maintained. The simple thing is when dealing with nonmuslim people who formed the majority group, then they might be careful and could maintain their behavior. However, the majority of non-Muslim environment would provide a psychological burden, especially to perform activities, especially worship prayers or others. One people explained that "in the majority of nonMuslim social life, we must be careful in doing something. For example, to call prayers or adzan, we do not use loud speakers, but we usually use low speakers".

Another parents added, "If we are fasting we only hold tarawih prayers in a small prayer room, because in our place there is no large mosque. After the prayer there is no the reciting Quran that uses 
speakers, so recite Quran in a low voice so as not to disturb people around".

The results of observations also showed that parents who were the subjects of the study often reminded inviting their children to pray at the prayer times. There were some people who directly did the prayer, but there are also some people who delayed the prayer time. In addition, parents invited their children to recite Qur'an especially after having a west prayers.

Based on the explanation above it can be understood that; besides parents must be diligent in reminding children to keep diligently doing compulsory worship, especially prayer 5 times and fasting.

\section{Strengthening in Education}

Parents, in this case the father or mother also had a special role in the family environment. For parents who have an understanding of education wanted that their children have education to a high level of education. In the Banjarasri region, Muslim parents had a large enough motivation to send their children to school. This was evident from children who were schooled to college or at least high school. It was in line with YS (one of the parents) who stated "the first child went to high school, even though I was only in elementary school, I wanted my child to be smart and high school. For my youngest child, I want to send him to university so that he can be successful unlike his parents".

Many parents in this environment directed their children to school in institutions that teach a lot about religious education. Mr. (S) said in the interview "here many parents sent their children to Islamic schools, even though in this village there is no Islamic school, children are sent to schools outside the village where there are Islamic schools in order to make their children to be smart in religious and general knowledge".

There were a belief from parents in this area, especially those who are Muslim, that schools were important, especially schools with a lot of religious knowledge would make children not affected negatively. It was also proven based on observations with many young people who came from Muslim minority families while maintaining their creed and worship. At a minimum they can be carried out their obligations as Muslims such as prayer and fasting, even in a predominantly nonMuslim environment. There were some parents based on observation in strengthening education willing to take and pick up their children to school far away from their village. It showed that parents really have strong role in educating their children to get sufficient religious and general material.

\section{Strengthening in Economics}

The role of religious leaders or ustadz in minority environment is to maintain creed, morals and islamic education as well as to seek support or assistance from outside the region, especially in economic matters to strengthen the resilience of Muslim minority families. Organizations or individuals provided routine assistance to keep the creed of Muslim communities especially those with low economics are important. According to EK (one of community leaders), he gave an explanation that "there are Muslim communities who are teachers, employees and hodge. People who usually work as employees and laborers who economically still need help. Sometimes there were nonMuslim communities who give help. It made us worry, because it can affect the creed. Now we have cooperation with Muslims around other villages or from mass organizations or figures who also routinely provide assistance. The hope is that actually we want the economy to have better jobs. But Alhamdulillah, for the time being, the concern of mass organizations and community leaders is enough to help". 
The economic condition of Muslim communities in Banjarasri especially those who worked as farmers or laborers could be a gap in the process of conversion to other religions. Among them are given economic assistance in the form of routine food or money.

Although there have not been cases of religious conversion, it cannot be denied that economic factors could be the reason for someone to convert. But the potential for it was always wide open because human psychics when under conditions of urgency would be able to do anything to solve the problem.

Economic conditions were still limited made obstacles that have an effect on worship activities. For example, strengthen the creed of the minority environment was access to places of worship. The mosque was not in the village, so it had to join in the surrounding village. The community has not been able to buy land and build a mosque that can be used for religious activities and strengthening Islamic education. Although this condition became an obstacle, but there were advantages that are obtained, namely the interaction with other communities presents closeness with the community around other villages where the majority of Muslims could strengthen the relationship and became a means to establish relationships with fellow Muslims. One of them is assistance that is often given to poor people who were Muslim during the fasting month or other times.

Another factor became an obstacle in strengthening religious education within the minority community in the banjarasri village of Yogyakarta is the exodus or transfer of young people who have a rather high education to move to the city. The motivation for moving on average is to find a decent job. It was in line with the results of interviews from community leaders (ST) who stated "many children who have gone to school outside do not want to return to their camps. Most of them are looking for work in the city, whether they are teachers, become factory workers, or try to open small businesses in the city".

Based on the results of the interview it could be understood that the constraints of young people starting to move to urban areas have their own impact on regeneration in minority communities in the village of Banjarasri. This factor was also one of the causes that inhibits moral development, where one side will emerge a negative influence from the blurring of religious education values in the eyes of the younger generation (Darajat, 1992). Where in the city environment interaction and friction with other cultures were more free and less controlled unlike in the village. In addition, there was also a dilemma in the lives of the younger generation, namely one side wants to change a better life by following the changing times or choosing to stay in an environment that they did not feel suitable because they already know and follow city life.

This result is supported by the observation of researchers, that many older people who already have teenage children who start working outside the area, for example, became a builder in the city or became a shopkeeper in the shops.

\section{DISCUSSION}

The family resilience for minority Muslims is a basic need for them in living their daily lives in the middle of other religious majority groups. The presence of the family as the main bastion in becoming a creed and equipping special interaction abilities for children in non-Muslim communities was absolutely necessary. One way to maintain family resilience and strength were the provision of a strong religious education and foundation of belief. This is in accordance with the results of research by Adawiyah and Jamaluddin (2016), where in the majority of Muslims living in non-Muslim environments, Islamic education 
engineering must be made to strengthen the community, especially Muslim families.

Islamic religious education was education through Islamic teachings in the form of guidance and care for students so that after completion of education he could understand, live and practice the teachings of Islam that he has believed in as a whole, and made the teachings of Islam as his outlook on life (way of life) for the sake of safety and welfare in the world and in the hereafter (Daradjat, 1996). In the context of life in the Banjarasri community which incidentally became a minority Muslim, the teachings of Islam have became a hereditary view of hereditary. Where parents taught to strengthen creed wherever they were. Because good Muslims were able to practice their religion wherever they were. Banjarasri society has proven it by the absence of friction or conflict with non-Muslim communities so far.

The existence of religious education aimed to instill faith and piety in each individual, as well as shape human morals so that individuals become noble and virtuous individuals in accordance with Islamic religion. A dept understanding of religious teachings would affect the attitudes and behavior of individuals in everyday life. One of them is about interaction with the surrounding environment that is different from religion, culture and society (Ulum, 2016).

Parents had an important role and heavy duty to teach religious education in the family environment. When parents provided understanding, experience and knowledge about community life for children, then there were demands that must be met by parents, namely adequate and sufficient abilities. Religious education is intended to increase spiritual potential and shape students to become human beings who believe and fear God Almighty and have good character. Noble morals include ethics, manners, and morals as an embodiment of religious education
(Wahab, 2010). Increasing spiritual potential included the introduction, understanding and inculcation of religious values as well as the practice of these values in individual and collective community life. The increase in spiritual potential was ultimately aimed at optimizing the various potentials possessed by humans whose actualization reflects their dignity and dignity as God's creatures. Strong relations between minority Muslim families are a necessity. Limited access in government, education and worship facilities is a challenge in living a social life (Adawiyah \& Jamaluddin, 2016). This also happened in the Banjarasri community, where the lack of religious facilities and religious schools was one of the obstacles in carrying out observance in the religious field. A completed model or system is needed to deal with this condition. Another challenged for Muslim minorities was limited access to social facilities and worship. Therefore, we needed support from external or outside the region in providing resilience for Muslim minority families.

Based on the results of this research there was a conceptual framework in religious education in the minority environment that is obtained. Family resilience started from strengthening education, economic and social values. Strengthening from the aspect of education, social and economics was carried out after an inventory of the strengths and weaknesses of Muslim minority communities. Another factor in this strengthening was the existence of strong relationships or networks among the surrounding Muslim communities. The interaction and strengthening of family resilience can be seen in the picture below: 
Picture 1

The Process of Strengthening Family Resilience

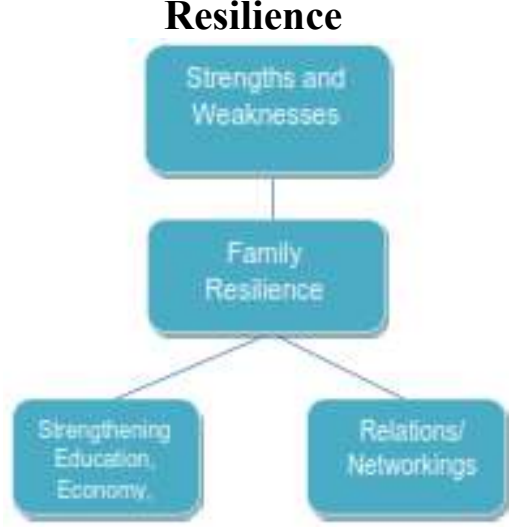

The results of the research showed several important points in strengthening religious education to form family resilience in the Muslim minority community in the village of Banjarasri. First, parents have done a simple understanding and religious education in the family environment. The environment had an important role in the cultivation of creed and the formation of children's morals. This was evident from what is done by parents by always reminding to keep on praying and fasting despite the environment of the majority of nonMuslims. Reinforcement done by parents is at least a form of understanding to their children that creed and worship are mandatory and important.

Second, another important meaning of the findings was the role of community leaders who were able to provide strong motivation to parents, especially to keep educating their children with good understanding and examples. Community leaders also had an important role in finding solutions that are faced by parents, for example, it related to disk education by giving directions to enter schools that have sufficient religious education.

Even though it has been done well, but in accordance with the picture of the process of strengthening family resilience from the aspect of religious education, there were great opportunities faced by the community in terms of economy and education. Educational facilities were not widely available in their environment. Children must go to school outside the village area of Banjarasri, which had a distance from the place of residence. Economic factors become one aspect that needs to be watched out for. The profession of work done by parents does not have a lot of results in the economic sector, because they are mostly farmers and laborers.

\section{CONCLUSION}

The conclusion of this research was that in dealing with problems in strengthening family religious education in the village of Banjarasri, the community has taken several steps. First, there were activities that have been carried out by Muslim minority families in the village of Banjarari Kulon Progo Yogyakarta to improve family resilience from the aspect of religious education in the form of increasing religious knowledge at the family and school level. At the family level, the form of strengthening was to provide understanding to children about the importance of creed and morals. Parents also gave an example by performing compulsory worship in a disciplined manner. Providing motivation and examples in carrying out obligations as a Muslim, such as always reminding to keep on praying five times and fasting during the holy month of Ramadan even in limited conditions and in a minority environment. Second, parents in the Muslim minority area in Banjarasri sent their children to schools based in religion. To add and increase knowledge and understanding of Islamic religious education. Third, in the economic aspect some religious leaders and young people who already have relationships in other places, established relationships and routinely inform the environmental conditions of the community, so that there was a lot of help from outside parties both from mass organizations or individuals in helping the community's economy. 
REFERENCES

Achmadi. (1992). Islam sebagai Paradigma Ilmu Pendidikan. Yogyakarta: Aditya Media.

Adawiyah, Rabiatul. Jamaluddin Z, Wan. (2016). Rekayasa Pendidikan Agama Islam di Daerah Minoritas Muslim . Tadris. 1(02),119-133.

Ahmad, Choirul. (2013). Pendidikan Multikultural. Yogyakarta: Pustaka Pelajar.

Al Arifin, Akhmad Hidayatullah.(2012). Implementasi Pendidikan Multikultural dalam Praksis Pendidikan di Indonesia. Jurnal Pembangunan Pendidikan: Fondasi dan Aplikasi. (1), 1, . 72.

An Nahlawi, Abdurrahman. (2010).. Ushulut Tarbiyyatil Islamiyah Wa Asalibuha. Jakarta: Logos Wacana Ilmu.

Anna, De Fina \& Georgakopoulou, Alexandra. (2015). Handbook of Narrative Analisys. New York : Wiley Blackweel.

Arifin, Syamsul., Bachtiar, Hasnan., Fuat, Ahmad Nur., Tongat., \& Wahyudi., (2019). Minority Muslims and freedom of religion: learning from Australian Muslims' experiences. IJIMS 9 (2), 295 -356.

Aziz, Erwati. (2003). Prinsip-prinsip Pendidikan Islam. Solo: Tiga Serangkai.

Ch, Mufidah. (2008). Psikologi Keluarga Islam. Malang: UIN Malang Press.

Creswell, J. W. (2007). Qualitative inquiry \& research design: Choosing among five approaches (2nd ed) USA: Sage publications.

Creswell, John. (2013). Research design qualitative, Quantitative and mix methods Aprroaches. USA: Sage Publication.

Czarniawska, B (2004). Narrative in Social Science research. London : Sage Publishing.

Darajat, Zakiyah (1992). Kerjasama guru dan orang tua dalam pembinaan akhlak anak. Pontianak : IAIN Press

Darajat, Zakiyah (1996). Ilmu Pendidikan Islam. , Jakarta: Bumi Aksara.

Desa Banjarasri. (2015).Monografi Desa Banjarasri Kalibawang.

Esposito, John L. (2002). Ensiklopedi Oxford Dunia Islam Modern,. Bandung: Mizan.

Kementerian Agama. (1971). Al Quran Dan Terjemahan. Jakarta : Kementerian Agama.

Libriyanti. Yuyun,. (2013). Pendidikan Agama Islam dalam masyarakat pluralis (Studi Tentang PAI Pada Kelas XII SMA Se-Kabupaten Klungkung Bali. Jurnal Pendidikan Agama Islam, 3(. 2.), 34-49.

Mc Donald, Frederick J. (1959). Educational Psychology. USA: Wadsworth Publishing.

Morries, W. (1973). The American Heritage Dictionary of English Language. Boston: Houghton Miffin.

Nizar, Syamsul (2013). Sejarah Pendidikan Islam. Jakarta: Kencana Prenada Media Group.

Prasetiya, B. (2019). Mengungkap analisis dan evaluasi kebijakan tentang pendidikan agama dan keagamaan. Conciencia, 19(2), 99-111.

Rahim Faqih, Aunur. (2001). Bimbingan dan Konseling dalam Islam. Yogyakarta: UII Press. 
Rianawati, W. (2019). Pendidikan Agama

Islam Pada Anak Usia Sekolah

Dasar Dalam Keluarga Di

Kecamatan Pemangkat Kabupaten

Sambas. Conciencia, 19 (2), 142156.

Shihab, Alwi. (1995). The Muhammadiyah

Movement and It's Controversy with Christian Mission

Dissertation, Temple University.

Supardi, Iwan. (2013). Pengembangan

Model Pendidikan Multikultural untuk Masyarakat Multietnis Kota Pontianak. Yogyakarta : Disertasi Program Pascasarjana Universitas Negeri Yogyakarta.

Syamil Al-Qur'an. (2010).Syamil AlQur'an Terjemah Tafsir Per kata. Sygma Publishing.

Tuanku Khatib, Ramayulis. (2001). Pendidikan Islam dalam Rumah Tangga. Jakarta: Kalam Mulia.

Ulum, miftahul itah., (2016). Desain Pendidikan Agama Islam Di Perguruan Tinggi Umum Berbasis Evolusi Budaya. Jurnal pendidikan Islam VIII (1),53-64.

Wahab. (2010). Pelaksanaan Pendidikan Agama Pada SMA Swasta (Studi Komparatif Perilaku Keagamaan di SMA Al Islam I dan SMA Batik 2 Surakarta).Analisa, XVII (01), 45 160.

Wahib, Abdul. (2012). Pergulatan Pendidikan Agama Islam di kawasan minoritas muslim di Bali. Jurnal Walisongo, IAIN Walisongo Semarang, 19,(2), 458-474. 